\title{
HER2 Assessment in Gastric Carcinoma
}

\section{Mide Kanserlerinde HER2 Değerlendirmesi}

\author{
Sultan Çiğdem Irkkan
}

Dr. A. Y. Ankara Onkoloji Eğitim Ve Araştırma Hastanesi, Patoloji Kliniği, Ankara, Türkiye

Dergiye ulaşım tarihi: 09/11/2014, Dergiye kabul tarihi:25/12/2014 Doi: 10.5505/aot.2014.24633

\section{ÖZET}

İlerlemiş mide ve gastroözofageal bileşke karsinomlarında tedaviye Trastuzumab eklenmesi, Her2 pozitif tümörlü hastalarda sağkalım avantajı sağlamıştır. Bu tedaviden faydalanabilecek hastaların Her2 testi ile belirlenmesi gerekmektedir. Meme karsinomlarından sonra, mide karsinomlarında da Her2 testi patoloji laboratuarlarının günlük işleri arasına girmiştir. Mide karsinomlarında Her2 testi, meme karsinomlarındakine benzer özellikler içermekle birlikte, bilinmesi gereken farklı yönleri de vardır. Bu farklar, başlıca mide karsinomlarında Her2 pozitifliğinin daha heterojen olması ve karsinom hücre membranlarında, reseptörlerin bazolateral yerleşimlerinden kaynaklanmaktadır. Her2 testinde kullanılan immünhistokimyasal ve in situ hibridizasyon testleri, çoğu laboratuarda kullanılır testler arasında olmakla birlikte, skorlama kriterleri karışıktır ve doğru sonuç için deneyim gerektirmektedir. Bu testlerde doğruluğu sağlamak için analitik koşullar kadar preanalitik koşullar da etkilidir.

Anahtar Kelimeler: Mide neoplazmlar1, HER2

\begin{abstract}
Addition of Trastuzumab in treatment of advanced gastric and gastroesophageal carcinomas has provided benefits in overall survival of those with Her2 positive tumors. It is necessary to identify patients who can benefit from the treatment with Her2 test. Following breast carcinomas, Her2 testing in gastric carcinomas are also added to the routine work of pathology labs. Although Her2 test in gastric carcinomas has similar features with that of breast, it has some aspects to be known well. These aspects have arisen mainly because of heterogeneous Her2 positivity and basolateral settling of the receptors in gastric carcinoma cells. Although Her2 immunohistochemical and in situ hybridization tests are among routine tests of most laboratories, scoring criteria are complex and need experience for accurate results. In achieving accurate results in these tests, pre-analytical as well as the analytical conditions, are also effective.
\end{abstract}

Key words: Gastric neoplasms; HER2

\section{Mide Kanserlerinde HER2 Değerlendirmesi}

Onyedinci kromozom üzerinde yer alan HER2 protoonkogeni, hücre membranında yer alan erbB2 reseptör proteinini kodlamaktadır (1). $\mathrm{Bu}$ protein epidermal büyüme faktör reseptörlerinden birisidir. Aktive olduğunda, tirozin kinaz yolu ile hücre diferansiasyonu, apopitoz, adhezyon, migrasyon ve büyüme fonksiyonlarını etkiler (2). Hücre çoğalmasindan sorumlu sinyal ileti yolu üzerinde yer alması nedeniyle de, birçok kanser türünde etkilidir.

Sitoplazmik membranda HER2 reseptör sayısının, normal bir hücredekine oranla artmas1, yani reseptörün overekspresyonu, patoloji pratiğinde immünhistokimyasal
(İHK) yöntemle araştırılır (3). Reseptör proteinini kodlayan gen kopya sayisinın nükleusta artması, yani genin amplifikasyonu ise in situ hibridizasyon (İSH) yöntemi ile araştırılmaktadır (4). Meme karsinomlarında HER2 İHK ve İSH çalışmaları, prognostik ve prediktif bilgi vermesi nedeniyle rutin hale gelmiştir.

Memeden başka organların tümörlerinde de HER2 overekspresyonu ve amplifikasyonu tesbit edilmektedir (5). Mide karsinomlar1 bunlardan birisidir (6). HER2 durumunun mide karsinomlarında pozitif ya da negatif prognostik değeri belirlenememiştir, ancak ilerlemiş mide karsinomlu hastalarda prediktif değerinin gösterilmesiyle birlikte, mide karsinomlarında da HER2 testi çalışılmaya başlanmıştır (7). 
HER2 pozitifliği, meme karsinomlarında \%15-20 civarında görülmektedir (810). Mide karsinomlarında ise, \%5-30 arasında değişen bölgesel sıklıklar bildirilmektedir (1117). Meme tümörleri ile kıyaslandığında mide tümörlerinde HER2 pozitifliğinin değişken s1kl1kta görülmesi, bölgesel veya 1rksal nedenlere bağlanmaktadır (18). Ayrıca mide tümörlerinde HER2 testi tekniklerinin ve skorlama kriterlerinin standart olmayışı da bu değişkenlik için bir etken olarak görülmektedir (19). Midede HER2 pozitifliği s1klıkla intestinal tip gastrik karsinomlarda (\%32) görülmektedir (7). Daha nadir olarak diffüz (\%6) ve andiferansiye karsinomlarda da görülmektedir (7). Karsinom gelişim bölgesi olarak da en s1k gastroözofageal bölgede (\%33) HER2 pozitifliği izlenmektedir (7).

Trastuzumab HER2 reseptörlerine bağlanarak etki eden hümanize rekombinant monoklonal bir antikordur (20). İleri evre meme karsinomlarında gösterdiği sağkalım avantajı nedeniyle kullanılmaya başlanmış ve daha sonra erken evre karsinomlarda da tedavi seçeneği haline gelmiştir (21-25). Daha sonra, Trastuzumaba yanıtın mide karsinomu hücre dizilerinde de, meme tümörü hücre dizilerindeki kadar iyi olduğu görülmüştür (17). İlerlemiş ve metastatik mide ve gastroözofageal bileşke kanserlerinde kombine kemoterapi ve trastuzumab tedavisiyle, tek başına kemoterapiye göre sağkalım avantajının gösterilmesi, trastuzumabı mide kanserlerinde de tedavi seçeneği haline getirmiştir (7). Bu gelişmeyle birlikte günlük pratikte tüm yeni tan 1 alan mide kanserlerinde de HER2 İHK testi yapılması önerilir hale gelmiştir (26).

Trastuzumab tedavisi için doğru hasta seçimi önemlidir. Çünkü tedavi çok masraflı olup önemli yan etkileri de vardır. ToGA çalışmasında İHK 3+ tümörlerin hepsi yanısıra, İHK skoruna bakılmaksızın ISH pozitif tümörlerin de hepsi tedavi programina alınmıştır (7). Sonuçlara bakıldığında ise, kayda değer sağkalım avantajının, İHK3+ veya İHK2+/ISH+ tümörlerde olduğu görülmüştür (7). Bu sonuçlar üzerine Avrupa İlaç Ajans1 (EMA) ve Amerikan Gıda ve İlaç Dairesi (FDA), Trastuzumab'in ileri evre mide karsinomlarında kullanılmasını onaylamıştır (19). Mide karsinomlarında HER2 testi için EMA, ilk aşamada İHK uygulanmasını, ikinci basamakta IHK 2+ tümörlere de İSH uygulanmasını önermektedir. EMA, IHK 3+ veya İHK $2+/$ ISSH + olan tümörlerin tedavi için uygun olduğunu kabul etmektedir (27). FDA ise, trastuzumab tedavisine uygun tümörün belirlenmesinde ilk basamağın İSH olmasını ve İSH pozitif olanlarda, İHK ile de doğrulamayı önermektedir. FDA, İSH+ olup İHK 2+ veya $3+$ tümörleri tedavi için uygun kabul etmektedir. Türkiye'de ise İHK $2+$ veya $3+$ ve İSH pozitif tümörler tedaviye uygun kabul edilmektedir.

Ancak hasta seçiminde kullanılan, HER2 İHK ve İSH yöntemleri, sonuçların doğruluğunu etkileyen pek çok faktör barındırır. Test yöntemleri zor ve karışıktır. Meme tümörlerinde kullanılan testler ile aynı test kitleri kullanılmaktadır ve aynı preanalitik prensipler geçerlidir. Ancak değerlendirme kriterleri biraz farklıdır. Doğru değerlendirme için deneyim gerekmektedir (28). Meme tümörlerinde kullanılan skorlama kriterleri kullanıldığında, tedaviden fayda görebilecek mide tümörleri tedavi dişı kalabilmektedir (12). Bu durum, mide tümörlerinde görülen HER2 pozitifliğinin özelliklerinden kaynaklanmaktadır. Bu nedenle mide tümörleri için farklı skorlama kriterleri geliştirilmiştir.

\section{Mide tümörlerinde Meme tümörlerine göre HER2 durumundaki farklılıklar}

1. Hücre membranında çepeçevre-komplet boyanma bakımından farkl1lı: Meme tümörlerinde HER2 reseptörleri hücre membranının tüm yüzeyinde çepeçevre yerleşirken, mide tümörlerinde hücrelerin kolumnar şekil ve sekretuar fonksiyonlarına bağlı olarak, bazolateral veya lateral hücre membranında yerleşmektedir (12). Bu nedenle, meme tümörlerinde çepeçevre komplet membranöz pozitiflik gözetilirken, mide karsinomlarında bazolateral veya lateral membranöz pozitiflik görmek yeterlidir.

2. HER2 heterojenitesi: meme tümörlerinde \% 1-2 oranında HER2 heterojen pozitifliği görülürken, mide tümörlerinde \%5-50 gibi yüksek oranlarda görülmektedir (Resim 1) $(12,16,18,29,30)$. 


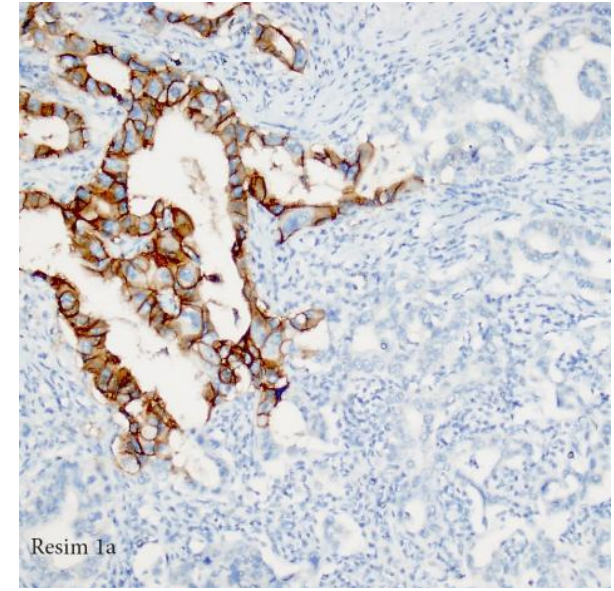

Resim 1a:Mide adenokarsinomunda klonal paternde Her2 İHK ekspresyonu (x40)

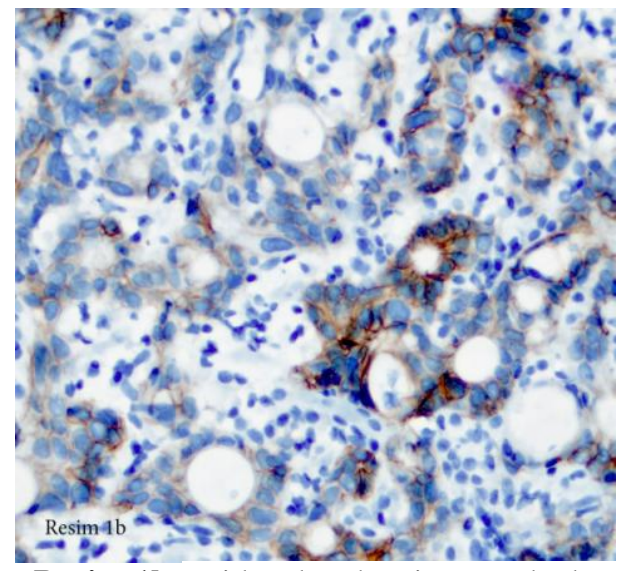

Resim 1b: Mide adenokarsinomunda dağ1nık (x40) paternde heterojen HER2 İHK ekspresyonu (klon: 4B5)

$\mathrm{Bu}$ nedenle, meme kor biyopsi ve eksizyonlarında ayn1 skorlama kriterleri kullanılırken, mide biyopsilerinde mide rezeksiyonlarındakinden farklı kriterler geliştirilmesi gerekmiştir. Meme karsinomlarında kor biyopsi ile saptanan HER2 durumu tümörün eksizyonel biyopsisinde saptanan ile yüksek korelasyon göstermektedir (29). Mide tümörlerinde ise heterojenite nedeniyle biyopsiler ile rezeksiyon materyali arasinda uyumsuzluklar olabilmektedir (16).

3. HER2 pozitifliği, meme tümörlerinde daha sıklıkla az diferansiye-yüksek dereceli tümörlerde izlenirken, mide tümörlerinde daha sıklıkla iyi diferansiye-intestinal tümörlerde görülür (7).

4. HER2 pozitifliği meme tümörlerinde kötü prognoz göstergesi iken, mide tümörlerinde bulgular, prognozla ilişkili olmadığını düşündürmektedir. Kötü prognozla ilişkili sonuçlar $(14,17,31-33)$ yanısıra iyi sonuçlar da alınmıştır $(34,35)$. Prognostik önemi olmadığını gösteren çalışmalar da olmaktadır $(18,30)$. HER2 skorlama kriterlerinin standart olmayışı sonuçlardaki çeşitliliğin nedeni olabilir (19).

\section{Mide tümörlerinde heterojenite ile başa çıkmak}

1. Metastatik ve ilerlemiş hastalıkta hasta çoğunlukla opere edilemez olduğundan, tümör örneği endoskopik biyopsi ile sinırlıdır. Mide tümörlerinde HER2 heterojenitesi nedeniyle pozitifliği atlamamak için endoskopik örnek sayısının 6-8 adet olmasi ve hepsinin test edilmesi önerilmektedir $(36,37)$. Tüm parçaların kesitleri mikroskopta taranmalı ve aydınlık alan İSH yöntemleri tercih edilmelidir (36).

2. Rezeksiyon materyallerinde tümörün intestinal diferansiye alanları veya diffüz tip karsinomlarda, tümörün solid alanları test için seçilmelidir (36).

3. Rezeksiyon materyallerinde tümörün farklı histomorfolojik alanlarını içeren bir ya da birden fazla blok test edilmelidir $(18,36)$.

4. İHK ve İSH yöntemlerini birlikte kullanmak da, özellikle endoskopik biyopsi örneklerinde heterojen pozitifliği atlamamak için bazı yazarlarca önerilmektedir (35).

\section{HER2 İHK skorlama Yöntemi}

ToGa çalışmasındaki tümörlerde HER2 durumu, daha önce Hofmann ve ark.'nın yaptıkları validasyon çalışması ile belirlenmiş kriterlere göre yapılmıştır (12). Yüzaltmışsekiz tümör örneğinde, İHK ve ISH uyumunun, \%93.5 oranında sağlandığı ön çalışmada önerilen bu kriterler, Tablo 1'de gösterilmektedir.

Tablo 1: Mide kanseri için HER2 skorlama önerisi (12) 


\begin{tabular}{|c|c|}
\hline Boyanma Özellikleri & Skor \\
\hline $\begin{array}{l}\text { Boyanma yok ya da \%10'dan } \\
\text { az tümör hücresinde } \\
\text { membranöz reaksiyon }\end{array}$ & 0/negatif \\
\hline $\begin{array}{l}\% 10 \text { 'dan fazla tümör } \\
\text { hücresinde zor seçilen/soluk ve } \\
\text { k1smi membranöz reaksiyon }\end{array}$ & $1+/$ negatif \\
\hline $\begin{array}{l}\text { \%10'dan fazla tümör } \\
\text { hücresinde zayıf/orta şiddette } \\
\text { komplet ya da bazolateral } \\
\text { membranöz reaksiyon }\end{array}$ & $\begin{array}{l}2+/ \\
\text { borderline } \\
\text { (İSH } \\
\text { gerekir) }\end{array}$ \\
\hline $\begin{array}{l}\% 10 \text { 'dan fazla hücrede } \\
\text { orta/kuvvetli komplet ya da } \\
\text { bazolateral membranöz } \\
\text { reaksiyon }\end{array}$ & $3+/$ pozitif \\
\hline $\begin{array}{l}\text { Biyopsi örneklerinde İHK3+ } \\
\text { ve/veya FİSH pozitif koheziv } \\
\text { bir klon* bulunmas1 pozitif } \\
\text { kabul edilmelidir (yani <\%10 } \\
\text { olsa da) }\end{array}$ & \\
\hline
\end{tabular}

$\mathrm{Bu}$ skorlama sistemine göre; boyanmanın paterni, bölgesi, şiddeti ve boyanma oranı dikkate alınmıştır. Tümörde boyanma membranöz ve komplet/ bazolateral/ lateral olduğunda pozitiflik için değerlidir. Sitoplazmik, nükleer, luminal, ya da bazal boyanma skorlamada kullanılmaz. Boyanmanın şiddeti; orta-kuvvetli olanlar skor3, hafif-orta olanlar skor2, zayıf-zor seçilenler skor1 olarak derecelendirilmektedir. Boyanan tümör hücresi oran1 rezeksiyonlarda en az \%10 ve üzerinde, biyopsilerde ise klonal bir hücre grubunda olmalıdır. Boyanma oranı \%10'un altında kaldığında, tümör bir alt skorda derecelendirilmiştir (Tablo 1). Skor 2 olarak derecelendirilen tümörlerde İSH ile amplifikasyon aranmalıdır. Skor 3 tümörler ile skor2 olup İSH ile amplifiye bulunan tümörler, tedavi için HER2 pozitif kabul edilmektedir. Skor 0 ve 1 tümörler ile Skor 2 olup İSH ile amplifiye bulunmayan tümörler HER2 negatiftir.

Hofmann'ın çalışmasında, biyopsilerde bir hücre grubu olarak kastedilen hücre miktarı 200 civarında hücre olarak belirlenmiştir (12). Ancak daha sonra bir klon olarak belirtilen hücre miktarının, subjektif bir ifade olmas1 ve uyumsuzluğu artırmas1 nedeniyle hücre miktarı en az 5 hücre olarak değiştirilmiştir (Resim 2) (27).

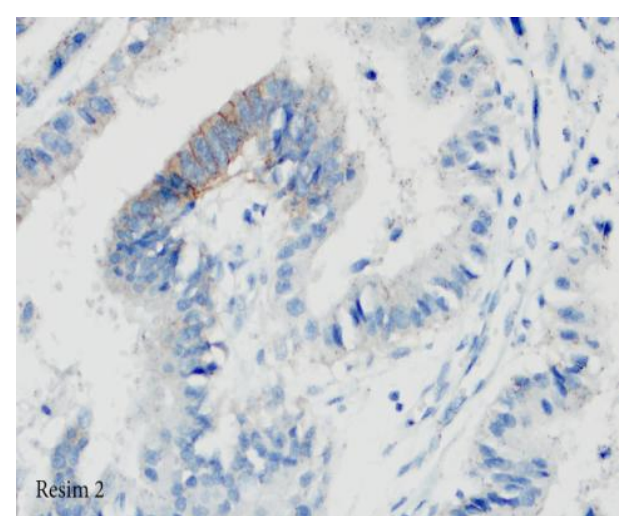

Resim 2: Endoskopik biyopsi materyalinde pozitiflik için, en az 5 hücre kriterini karşılayan, ardışık bir hücre grubunda, skor 2 şiddetinde membranöz pozitiflik (klon: 4B5, x40)

Çünkü gözlemciler arasında en fazla uyumsuzluğun yaşandığ hücreden daha az hücrede boyanmalar olduğu görülmüştür. $\mathrm{Bu}$ değişiklik ile biyopsilerde yanlış negatifliklerin önlenmesi amaçlanmıştır. Daha sonra gözlemciler arası uyumu yükseltmek ve mide HER2 skorlamasını daha standardize hale getirmek için, İHK boyanma şiddetini değerlendirmede 'büyütmeler kuralı' geliştirilmiştir (27). Bu yöntemle, gözlemciler arasında \%92.5 uyum sağlandığı görülmüş ve yaygın olarak uygulanmaya başlanmıştır. Buna göre skoru belirlemede, membranöz boyanmanın seçilebildiği mikroskop büyütmesi, skora karar vermekte yol gösterici olmaktadır (Tablo 2).

Tablo 2: İHK boyanma şiddetinin belirlenmesinde büyütmeler kuralı (27)

\begin{tabular}{|l|l|}
\hline Skor 3 & $\begin{array}{l}\text { Lam üzerinde mikroskopsuz } \\
\text { görülebilen, ya da küçük } \\
\text { büyütmelerde (x2-x5) görülebilen } \\
\text { güçlü membranöz boyanmadır. }\end{array}$ \\
\hline Skor 2 & $\begin{array}{l}\text { x10-x20 büyütmelerde görülebilen } \\
\text { zayıf-orta şiddetteki membranöz } \\
\text { boyanmadır. }\end{array}$ \\
\hline Skor 1 & $\begin{array}{l}\text { X40 büyütmede görülebilen zor } \\
\text { seçilen membranöz boyanmadır. }\end{array}$ \\
\hline
\end{tabular}

Çıplak gözle, lam üzerinde de görülebilen, ya da düşük büyütmede $(x 2.5 / \times 5)$ görülebilen membranöz boyanma skor 3 olarak değerlendirilmektedir. Orta büyütmelerde (x10/x20) görülebilen boyanma skor 2, yüksek büyütmede $(\mathrm{x} 40)$ görülebilen boyanma skor 1 olarak değerlendirilmektedir (Resim 3). 


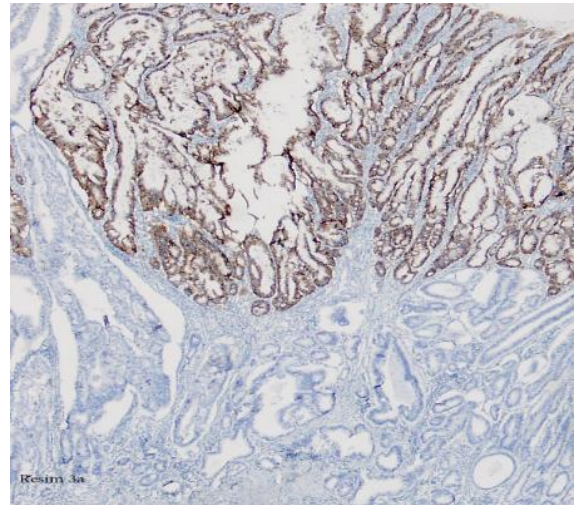

Resim 3a: İHK boyanma şiddetinin değerlendirilmesinde (4B5), 'büyütmeler kuralı", na göre a) düşük büyütmelerde görülebilen, güçlü (skor 3) (x4)

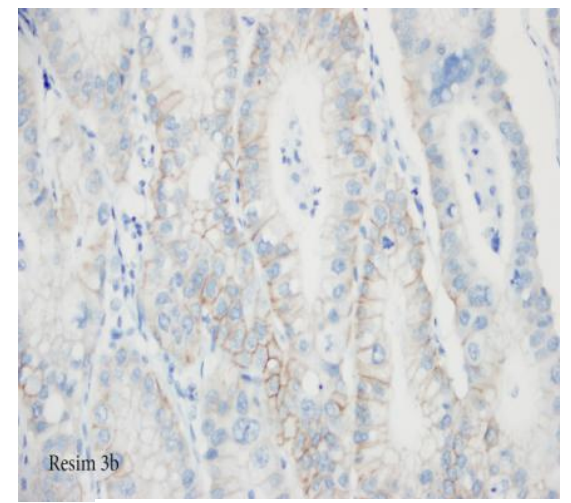

Resim 3b: Orta büyütmelerde görülen, orta-zayıf (skor 2) (x20)

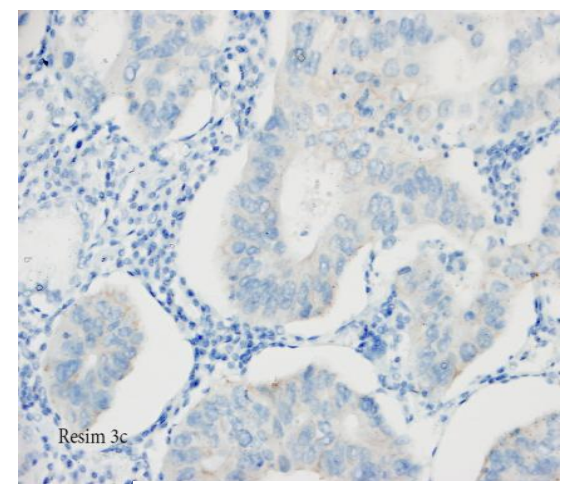

Resim 3c: Yüksek büyütme ile görülen zor seçilebilir özellikte (skor 1) membranöz HER2 pozitifliği (x40).

Düşük büyütmelerde seçilebilen boyanmanın daha büyük büyütmelerde gerçek membranöz boyanma olduğu doğrulanmalı ve submembranöz sitoplazmik granüler boyanmalar ekarte edilmelidir. Yüzde on miktara ulaşmayan kuvvetli membranöz boyanma görüldüğünde, tümör heterojenitesi nedeniyle başka tümör bloklarında da İHK çalışma tekrarlanabilir (19). Diffüz sitoplazmik veya nükleer boyanma gösteren nadir tümörlerde de İSH ile amplifikasyon bildirilmiş olması nedeniyle, beklenmeyen boyanmalarda da İSH ile doğrulama yapılması önerilmektedir $(19,27)$.

\section{HER2 IHHK testinde izlenen tuzak ve artefaktlar}

Mide tümörlerinde HER2 testi patologlar için yeni ve karmaşık olduğu kadar, skorlamay1 etkileyecek çeldirici özellikler de içermektedir. $\mathrm{Bu}$ özelliklerin, testi yapan patolog tarafindan iyi bilinmesi önemlidir.

1. İntestinal metaplazi ve reaktif değişiklikler gösteren mide mukozasında görülen artefaktif boyanma: $\mathrm{Bu}$ tür boyanmaların, validasyonu yapılmış bir antikor olan 4B5 antikoru ile izlendiği belirtilmektedir (27) (Resim 4).

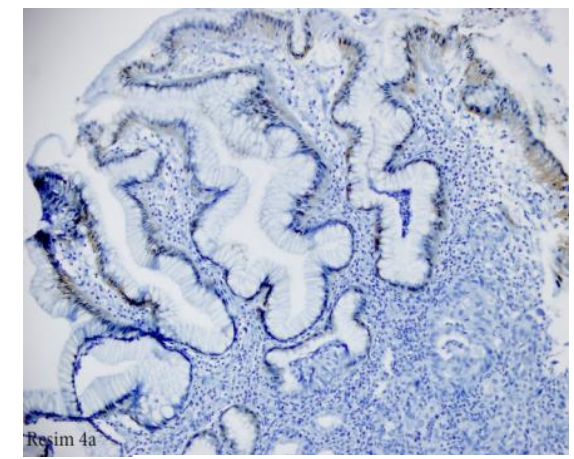

Resim 4a: HER2 4B5 antikoru ile, a) reaktif mide mukozasında bazal sitoplazmik (x20)

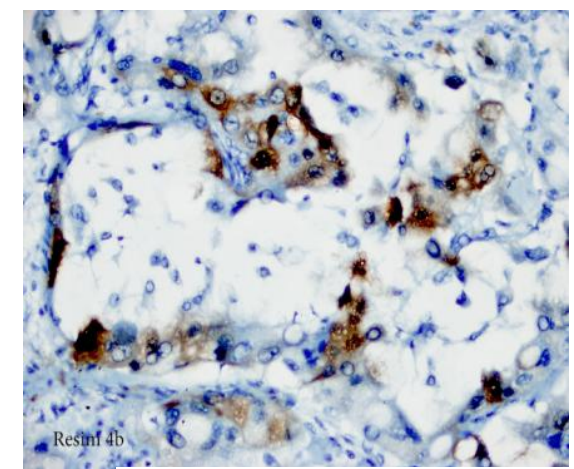

Resim 4b: Tümörde önemi bilinmeyen nükleer ve sitoplazmik boyanma $(\mathrm{x} 40)$

$\mathrm{Bu}$ antikor kullanıldığında, metaplastikreaktif değişiklik alanları yanlış olarak tümördeki boyanma olarak değerlendirilmemelidir.

2. Kenar artefaktı: Doku kenarlarına rastlayan tümör sitoplazmalarında görülen, granülerpsödomembranöz boyanmaların, kenar artefaktı olduğu bilinmeli ve skorlanmamalıdır (27). Bu durum, özellikle 
endoskopik biyopsiler ve kor biyopsilerde iyi bilinen ve dikkat edilmesi gereken bir durumdur.

3. Luminal boyanma: Tümörde luminal yüzeyde oluşan boyanmalar dikkate alınmamalıdır. Nonspesifik artefaktif bir renklenmedir.

4. Nükleer ve sitoplazmik boyanma: Önemi henüz belli değildir. Nonspesifik olduğu düşünülmektedir. Bu boyanma pozitif kabul edilmek yerine önemi anlaşılamamış olduğundan İSH ile araştırılmalıdır (Resim 4) (27).

5. İHK testi optimize edilmelidir: İmmün boyanma skorlanmadan önce, boya kalitesi kontrol edilmelidir $(27,36)$. Her zaman pozitif kontrol kullanılmalıdır. Doku içerisindeki negatif kontroller de gözden geçirilmelidir. Boyanmaması gereken lenfositler, endotel hücreleri gibi hücrelerde boyanma olduğunda antikorun inkübasyon süresi ya da konsantrasyonunun fazla olduğu ve tümörde yanlış pozitifliğe sebep olabileceği unutulmamalıdır.

\section{HER2 İSH değerlendirilmesi}

İHK ile kıyaslandığında, İSH yöntemi daha maliyetli, biraz daha uzun zaman alan ve daha deneyimli merkezi laboratuarlarda kullanılan bir yöntemdir. HER2 testinde izlenen algoritmada, Avrupa'da İHK sonucunda gerekli durumlarda İSH yöntemine başvurulurken, Amerika'da İHK ya da İSH testinden biri ile HER2 testine başlamak ve borderline sonuçlarda diğerini kullanmak önerilmektedir. İHK'da herhangi bir belirsizlik durumu görüldüğünde de İSH testi yapılmalıdır (19).

Flöresan İSH (FİSH) yöntemi, meme karsinomlarında HER2 testi için uzun süredir kullanılan, doğruluğu kanıtlanmış ve altın standart olarak kabul edilen bir yöntemdir. İSH tekniği olarak sadece genin test edildiği mono prob yöntemler yanısıra, dual yöntemler de kullanılabilir. Dual İSH yöntemleri, HER2 geni ve Kromozom17 sentromerinin birlikte, ayn1 hücrede farklı renklerde kromojen veya 1şıma ile işaretlendiği, ve gen/kromozom oranının belirlenebildiği yöntemlerdir. Aydınlık alan dual İSH (BDISH) yöntemi de son yıllarda geliştirilmiş ve FISH ile korele bulunmuştur $(38,39)$. Tüm doku kesitinin zaman sınırlaması olmadan ve morfoloji eşliğinde değerlendirilebilmesi avantajına sahiptir. Ayrica, boyanan lamlar FİSH'in aksine, solmadan arşivlenebilmektedir. ToGA çalışmasında FİSH yöntemi kullanılmış olmakla birlikte, bu yazıda mide karsinomlarında heterojenite ile başa çıkmada faydalı olduğu için tercih edilen, BDISH yönteminden bahsedilecektir.

İmmün değerlendirmede olduğu gibi, önce boyanma kalitesi kontrol edilmelidir. Tümör stroması, lenfositler ve tümörsüz mide mukozasındaki sinyaller gözden geçirilmelidir (36). Bu hücrelerde her hücrede ikişer kopya bulunmas1 gereken HER2 geni ve kromozom 17 sinyallerinin görülmesi, reaksiyonun gerçekleştiğini göstermektedir (Resim 5).

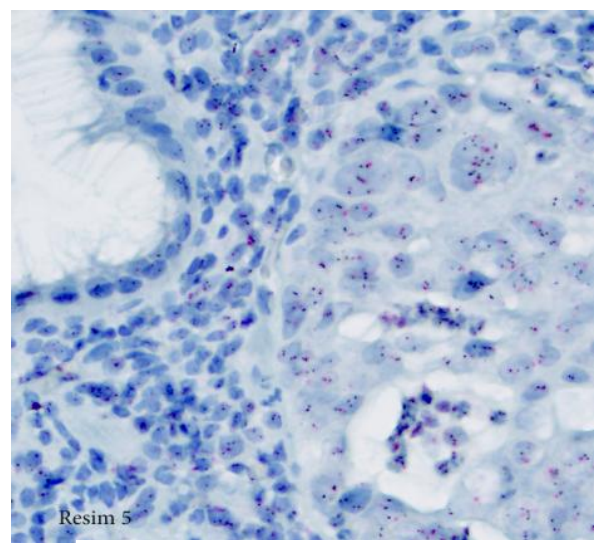

Resim 5: BDISH yönteminde iç kontrolü oluşturan mide mukozası ve lenfositler yanısıra tümörde yeterli gen (siyah) ve kromozom (kırmızı) sinyallerinin görülmesi $(\mathrm{x} 100)$

Hücrenin bir kısmının kesitte bulunmaması (trunkasyonu) nedeniyle bazı hücrelerde bu sinyallerin sayısı birer adet olabilir, ya da sinyallerin rastlamadığı hücreler de olabilir. Gen ve kromozom sinyallerinin her ikisinin de izlendiği hücreler değerlendirmeye alınmalıdır. Trunkasyona uğrayan hücreler değerlendirmeye alınmamalıdır (36). Reaksiyonun yeterli kabul edilebilmesi için tümör hücrelerinin $\% 70$ kadarında sinyaller belirmiş olmalıdır. Daha az miktarda hücrede sinyal izleniyorsa, test daha güçlü bir protokolle tekrar edilerek, sinyaller ortaya çıkarılmalıdır.

Amplifiye tümörlerde üstüste izlenen gen sinyalleri, bir normal sinyal büyüklüğü dikkate alınarak sayıca hesaplanmaya çalışılmalıdır. Birbirine dokunan ya da bir sinyal büyüklüğünden daha yakın olan sinyaller, "ikiz sinyal" olarak adlandırılmaktadır. İkiz sinyaller mitotik hücrede, ayrılmaya başlayan kromatin eşlerine ait olup, tek sinyal olarak sayılmalıdır. 
İSH lamı önce düşük ve orta büyütmelerde taranmalıdır. İmmün lamında görülen reaksiyon alanı ile yönlenerek tarama da faydalıdır. Tarama ile tüm alanlardaki sinyaller gözden geçirilmeli ve klonal heterojenite bulunması durumunda farklı olan alanlar, ayrı ayrı sayılmalıdır (Resim 6).

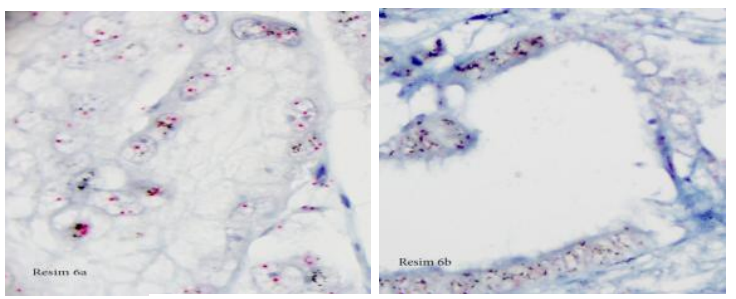

Resim 6a: BDISH yönteminde a) amplifiye olan ve olmayan tümör hücrelerinin karışık izlendiği, dağınık paternde (x100) ve b) amplifiye hücrelerin (solda) nonamplifiye hücrelerle (sağda) keskin geçiş gösterdiği, klonal paternde (x100) HER2 heterojenitesi.

Sayılacak hücrelerin üstüste binmemiş olmalarına dikkat edilmelidir. Üstüste binme, ince kesit alınarak önlenebilir. Belirlenen bir hücre grubunda, 20 ardışık hücrede ve $\mathrm{x} 40$ büyütmede gen ve kromozom sinyalleri sayilır. Patoloji raporunda gen/kromozom oran1, hücre başına HER2 sinyal ortalaması ve hücre başına kromozom 17 ortalaması belirtilmelidir (Tablo 3).

Tablo 3: İSH sinyallerinin değerlendirilmesi.

\begin{tabular}{|c|c|c|c|c|}
\hline \multicolumn{2}{|c|}{ Mono Prob İSH } & \multicolumn{3}{|c|}{ Dual Prob İSH } \\
\hline \multicolumn{2}{|c|}{ Ortalama gen } & \multicolumn{3}{|c|}{ Gen/kr ORANI } \\
\hline$\geq 6$ & pozitif & \multicolumn{2}{|l|}{$>2$} & pozitif \\
\hline $4-5$ & borderline* & \multirow{3}{*}{$<2$} & $\begin{array}{l}\text { Ort gen } \\
>6\end{array}$ & pozitif \\
\hline \multirow[t]{2}{*}{$<4$} & \multirow[t]{2}{*}{ negatif } & & $\begin{array}{l}\text { Ort gen } \\
4-5\end{array}$ & borderline* \\
\hline & & & $\begin{array}{l}\text { Ort gen } \\
<4\end{array}$ & negatif \\
\hline
\end{tabular}

* Birkaç set 20 hücre daha sayıma eklenmelidir.

Kullanılan İSH yönteminin mono veya dual oluşuna göre sonuçlar değerlendirilir. Mono prob testlerde hücre başına gen ortalaması 6 ve üzerinde olduğunda, sonuç pozitif kabul edilmektedir. Gen ortalamas1 4'den az olduğunda sonuç negatif, 4'den büyük 6'dan küçük olduğunda ise borderline kabul edilmektedir (Tablo 3). Borderline sonuçlarda, ek 20 hücrelik setler ortalama hesaplamasina eklenir. Borderline aralıkta kalmaya devam eden tümörler, dual İSH yöntemi ile tekrar çalışılmalıdır. Dual prob kullanıldığında gen/kromozom oranına göre test yorumlanır. Oran 2 ve üzerinde olduğunda sonuç pozitif kabul edilmektedir. Oran 2'den küçük olduğunda test negatiftir. Ancak ilk 20 hücre sayıldığında, oran 1.8 ile 2.2 arasında ise, sonuca karar vermeden önce, ek 20 hücrelik setler sayılarak, ortalama hesaplanmasina eklenmelidir (18).

Meme tümörlerinde gen sayısının gen/kromozom oranından daha önemli olabileceğine dair bulgular ve görüşler bulunmaktadır (40). Gen/kromozom ortalamas1 2 'den küçük olan tümörler içerisinde, gen ve kromozom sayısı yüksek olanlar; yani polizomik olanlar, normal olanlardan farkl1 olabilir. Gen/kromozom oranı 2'den küçük olsa da, gen ortalaması 6'dan büyük olan meme tümörlerinin tedaviye iyi cevap verdiklerini gösteren bulgular vardır (41). Meme tümörlerinde polizomiye bağlı artmış gen kopya sayısı $(>6)$ Amerikalı Klinik Onkolog ve Patolog Toplulukları (ASCO/ CAP) tarafindan tedavi için uygun kabul edilmektedir (42). Meme karsinomlarında olduğu gibi, mide karsinomlarında da dual prob kullanıldığında, gen ortalamasını dikkate almak-patoloji raporunda belirtmek konusunda öneriler vardır (36).

\section{İSH değerlendirmesinde Sorunlar}

1. Gastrik biyopsi materyalinde sadece 5 hücre amplifiye ise, bu hücreleri içeren 20 hücre sayılmalıdır.

2. Kuruma artefaktı iyi bilinmeli ve bu durumda zeminde izlenen gümüş partikülleri yanlış olarak pozitif kabul edilmemelidir.

3. İSH yöntemi de İHK yöntemi gibi preanalitik koşullara hassasdır. Uzun fiksasyon süresine bağlı zayıf sinyal, ya da sinyal yokluğu oluşabileceğinden, laboratuvarda fiksasyon sürelerine dikkat edilmeli ve standardize edilmelidir.

\section{HER2 testini etkileyen faktörler}

1. Heterojenite nedeniyle biyopsi materyalinde yanlıș negatiflik: Endoskopist özellikle ameliyat olamayacak, ileri evre 
hastalarda yeterli miktarda parça örneklemelidir. Bir çalışmada heterojen HER2 immünreaktivitesi bulunan tümörlerde HER2 amplifikasyonunun HER2 overekspresyonu olmayan bölgelerde tesbit edildiği görülmüştür (18). Bu nedenle, bazı yazarlarca, ilk basamakta İHK'nın uygun hastayı atlayabileceği göz önüne alınarak, biyopsilerde her zaman İHK ve İSH'nın birlikte kullanılması görüşü vurgulanmaktadır.

2. Testin uygun preanalitik koşullar gerektirmesi: Soğuk iskemi süresi, fiksatifin türü ve fiksasyon süresi gibi preanalitik koşulların, meme tümörlerinde HER2 değerlendirmesinde etkili olduğu, ve bu nedenle preanalitik koşulları sağlamanın önemi bilinmektedir (43). Mide tümörlerinde bu koşullar hakkında çalışma bulunmadığından, meme için önerilen koşulların mide materyalinde de sağlanması akla uygun gözükmektedir (19). Biyopsi veya cerrahi materyalin bir an önce ve yeterli miktarda \%10 nötral tamponlu formalin içerisinde, patoloji laboratuarına gönderilmesi sağlanmalıdır. Patoloji laboratuarında gastrektomi spesmenleri biran önce açılarak en kısa zamanda gastrik lümenin fiksatife ulaşması sağlanmalıdır. Fiksatife girene kadar geçen soğuk iskemi süresi 1 saati aşmamalıdır. Fiksasyon süresi, meme materyalleri için önerildiği gibi, küçük ya da büyük tüm materyallerde 6 ile 72 saat arasında tutulmalıdır. Doku takibinde 60 derece üzerinde sicaklık uygulanmamalı, alkol fiksasyonu ve hizlı takip yapılmamalıdır.

3. HER2 testinde gözlemci içi ve gözlemciler aras1 uyumsuzluk: HER2 testinin sürekli bu testi yapan merkezlerde, tercihen de yılda en az 100 test yapan merkezlerde yapılmas1 önerilmektedir. Mümkünse bu testin belirlenmiş birkaç patolog tarafindan yapılmas1 sağlanmalıdır. Mide HER2 testinin de, meme HER2 testi konusunda deneyimli merkezlerde çalışılması, uyumsuzlukla başa çıkmakta faydalı olacaktır.

\section{HER2 testi kalitesi için öneriler}

1. Sonuç 5 gün gibi kısa bir süre içerisindehızlı verilmelidir. Mide karsinomlu hastalarda seyir çok hızlı olmaktadır.
2. Test için santral laboratuarlar tercih edilmelidir. Mide için merkezi bir laboratuar yoksa önceden meme için bu testleri yapan merkezler tercih edilmelidir.

3. Başlangıçta ilk 50 kadar tümörde İHK ile İSH birlikte çalışılarak laboratuar içerisinde testin doğruluğu kanıtlanmalıdır (validasyon).

4. Memede olduğu gibi, mide tümörlerinde de doğruluğu kanıtlanmış (valide) kitlerin kullanılması önerilmektedir (36).

\section{Metastatik tümör ile primer tümörün HER2 durumu}

Primer mide tümörü ile metastazında HER2 durumu uyumunu araştıran çalışmalar da yapılmaktadır (44-47). Bu çalışmalardan bir k1smında metastazlarda HER2 durumunun pozitifleştiği tesbit edildiğinden, primer tümörden başka, metastazın da test edilmesi önerilmektedir (19).

\section{Çıkar çatışması: Yok}

\section{Kaynaklar}

1. Akiyama T, Sudo C, Ogawara H, et al. The product of the human c-erbB-2 gene: a 185-kilo-Dalton glycoprotein with tyrosine kinase activity. Science 1986;232:1644-6

2. Coussens L, Yang-Feng TL, Liao YC, et al. Tyrosine kinase receptor with extensive homology to EGF receptor shares chromosomal location with neu oncogene. Science 1985;230:1132-9

3. King CR, Kraus MH, Aaronson SA. Amplification of a novel v-erbB2 related gene in human mammary carcinoma. Science 1985;229:974-6

4. Slamon DJ, Clark GM, Wong SG, et al. Human breast cancer: correlation of relapse and survival with amplification of the HER-2/neu oncogene. Science 1987;235:177-82

5. Slamon DJ, Godolphin W, Jones LA, et al. Studies of the HER-2/neu protooncogene in human breast and ovarian cancer. Science 1989;244:707-12

6. Fukushige S, Matsubara $K$, Yoshida $M$, et al. Localization of a novel verbB-related gene, c-erbB-2, on human chromosome 17 and its amplification in a gastric cancer cell line. Mol Cell Biol 1986;6:955-8

7. Bang YJ, Cutsem EV, Feyereislova A, et al. Trastuzumab in combination with chemotherapy versus chemotherapy alone for treatment of HER2positive advanced gastric or gastro-oesophageal junction cancer (ToGA): a phase 3, open-label, randomised controlled trial. Lancet 2010;376:687-97

8. Konecny G, Pauletti G, Pegram M, et al. Quantitative association between HER-2 / neu and steroid hormone receptors in hormone receptor-positive primary breast cancer. $\mathrm{J}$ Natl Cancer Inst 2003;95:142-53 
9. Owens MA, Horten BC, Da Silva MM. HER2 amplification ratios by fluorescence in situ hybridization and correlation with immunohistochemistry in a cohort of 6556 breast cancer tissues. Clin Breast Cancer 2004;5:63-9

10. Penault-Llorca F, Vincent-Salomon A, Mathieu MC, et al. Incidence and implications of HER2 and hormonal receptor overexpression in newly diagnosed metastatic breast cancer (MBC). J Clin Oncol (Meeting Abstracts) 2005;23;69s (Abstract 764)

11. Giuffrè G, Ieni A, Barresi V, Caruso RA, Tuccari G. HER2 status in unusual histological variants of gastric adenocarcinomas. J Clin Pathol 2012;65:23741

12. Hofmann M, Stoss O, Shi D, et al. Assessment of a HER2 scoring system for gastric cancer: results from a validation study. Histopathology 2008;52:797-805

13. Jorgensen JT. Targeted HER2 treatment in advanced gastric cancer. Oncology 2010;78:26-33

14. Kim JW, Im SA, Kim M, et al. The prognostic significance of HER2 positivity for advanced gastric cancer patients undergoing first-line modified FOLFOX-6 regimen. Anticancer Res 2012;32:154753

15. Kim MA, Jung EJ, Lee HS, et al. Evaluation of HER2 gene status in gastric carcinoma using immunohistochemistry, fluorescence in situ hybridization, and real-time quantitative polymerase chain reaction. Hum Pathol 2007;38:1386-93

16. Lee S, Boer WB, Fermoyle S, et al. Human Epidermal growth factor receptor 2 testing in gastric carcinoma: issues related to heterogeneity in biopsies and resections. Histopathology 2011;59:832-40

17. Tanner M, Hollme'n M, Junttila TT, et al. Amplification of HER-2 in gastric carcinoma: association with Topoisomerase IIa gene amplification, intestinal type, poor prognosis and sensitivity to trastuzumab. Ann Oncol 2005;16:273-8

18. Kunz PL, Mojtahed A, Fisher GA, et al. Her2 expression in gastric and gastroesophageal junction adenocarcinoma in a US population: clinicopathologic analysis with proposed approach to Her2 assessment. Appl Immunohistochem Mol Morphol 2012;20:13-24

19. Davison JM, Pai RK. Her2 assessment in upper gastrointestinal tract adenocarcinoma. A practical, algorithmic approach. Surg Pathol Clin 2013;6:391

20. Carter P, Presta L, Gorman CM, et al. Humanization of an antip185HER2 antibody for human cancer therapy. Proc Natl Acad Sci USA. 1992;89:4285-9

21. Cobleigh MA, Vogel CL, Tripathy D, et al. Multinational study of the efficacy and safety of humanized anti-HER2 monoclonal antibody in women who have HER2-overexpressing metastatic breast cancer that has progressed after chemotherapy for metastatic disease. J Clin Oncol 1999;17:2639-48

22. Piccart-Gebhart MJ, Procter M, Leyland-Jones B, et al. Trastuzumab after adjuvant chemotherapy in HER2-positive breast cancer. N Engl J Med 2005;353:1659-72

23. Romond EH, Perez EA, Bryant J, et al. Trastuzumab plus adjuvant chemotherapy for operable HER2positive breast cancer. N Engl J Med 2005;353:167384

24. Slamon DJ, Leyland-Jones B, Shak S, et al. Use of chemotherapy plus a monoclonal antibody against HER2 for metastatic breast cancer that overexpresses HER2. N Engl J Med 2001;344:783-92

25. Vogel CL, Cobleigh MA, Tripathy D, et al. Efficacy and safety of trastuzumab as a single agent in firstline treatment of HER2- overexpressing metastatic breast cancer. J Clin Oncol 2002;20:719-26

26. Mello RA, Marques AM, Araujo A. HER2 therapies and gastric cancer: a step forward. World J Gastroenterol 2013;19:6165

27. Rüschoff J, Dietel M, Baretton G, et al. HER2 diagnostics in gastric cancer-guideline validation and development of standardized immunohistochemical testing. Virchows Arch 2010;457:299-307

28. Kushima R, Kuwata T, Yao T, et al. Interpretation of HER2 tests in gastric cancer: confirmation of interobserver differences and validation of a QA/QC educational program. Virchows Arch 2014;464:53945

29. Lee AH, Key HP, Bell JA, et al. Concordance of Her2 status assessed on needle core biopsy and surgical specimens of invasive carcinoma of the breast. Histopathology 2012;60:880-4

30. Grabsch H, Sivakumar S, Gray S, et al. Her2 expression in gastric cancer: rare, heterogenous and of no prognostic value-cocnclusions from 924 cases of two independant series. Cell Oncol 2010;32:57-65

31. Dang HZ, Yu Y, Jiao SC. Prognosis of HER2 overexpressing gastric cancer patients with liver metastasis. World J Gastroenterol 2012;18:2402-7

32. Jorgensen JT, Hersom M. HER2 as a Prognostic Marker in Gastric Cancer-A Systematic Analysis of Data from the Literature. J Cancer 2012;3:137-44

33. Park DI, Yun JW, Park JH, et al. HER $2 /$ neu amplification is an independent prognostic factor in gastric cancer. Dig Dis Sci 2006;51:1371-9

34. Gomez-Martin C, Garralda E, Echarri MJ, et al. HER2/neu testing for anti-HER2-based therapies in patients with unresectable and/or metastatic gastric cancer. J Clin Pathol 2012;65:751-7

35. Janjigian YY, Werner D, Pauligk C, et al. Prognosis of metastatic gastric and gastroesophageal junction cancer by HER2 status: a European and USA International collaborative analysis. Ann Oncol 2012;10:2656-62

36. Rüschoff J, Hanna W, Bilous M, et al. HER2 testing in gastric cancer: a practical approach. Mod Pathol 2012;25:637-50

37. Moehler M, Al-Batran SE, Andus T, et al. German S3 Guideline "Diagnosis and treatment of esophagogastric cancer'. Gastroenterology 2011;49:461-531

38. Kosa C, Kardos L, Kovacs J, Szollosi Z. Comparison of dual-color dual-hapten brightfield in situ hybridization (DDISH) and fluorescence in situ hybridization in breast cancer HER2 assessment. Pathol Res Pract 2013;209:147-50

39. García-García E, Gómez-Martín C, Angulo B, et al. Hybridization for human epidermal growth factor receptor 2 testing in gastric carcinoma: a comparison of fluorescence in-situ hybridization with a novel fully automated dual-colour silver in-situ hybridization method. Hybridization for human epidermal growth factor receptor 2 testing in gastric carcinoma: a comparison of fluorescence in-situ 
hybridization with a novel fully automated dualcolour silver in-situ hybridization method. Histopathology 2011;59:8-17

40. Hanna WM, Rüschoff J, Bilous M, et al. HER2 in situ hybridization in breast cancer: clinical implications of polysomy 17 and genetic heterogeneity. Mod Pathol 2014;27:4-18

41. Seidman AD, Berry D, Cirrincione C, et al. Randomized Phase III Trial of Weekly Compared With Every-3-Weeks Paclitaxel for Metastatic Breast Cancer, With Trastuzumab for all HER-2 Overexpressors and Random Assignment to Trastuzumab or Not in HER-2 Nonoverexpressors: Final Results of Cancer and leukemia Group B Protocol 9840. J Clin Oncol 2008; 10:1642

42. Wolff AC, Hammond ME, Hicks DG, et al. Recommendations for human epidermal growth factor receptor 2 testing in breast cancer: American Society of Clinical Oncology/College of American Pathologists clinical practice guideline update. J Clin Oncol 2013;31:3997-4013

43. Wolff AC, Hammond MEH, Schwartz JN, et al. American Society of Clinical Oncology/College of
American Pathologists Guideline Recommendations for Human Epidermal Growth Factor Receptor 2 Testing in Breast Cancer. Arch Pathol Lab Med 2007;131:18-43

44. Bozzetti C, Negri FV, Lagrasta CA, et al. Comparison of Her2 status in primary and paired metastatic sites of gastric carcinoma. Br J Cancer 2011;104:1372-6

45. Kim MA, Lee HJ, Yang HK, et al. Heterogenous amplification of ERBB2 in primary lesions is responsible for the discordant ERBB' status of primary and metastatic lesions in gastric carcinoma. Histopathology 2011;59:822-31

46. Negri FV, Bozzetti C, Ardizzoni A, et al. Her2 discordance between primary gastric carcinoma and paired lymph node metastasis. Hum Pathol 2011;42:909-10 (author reply)

47. Perrone G, Amato $M$, Callea $M$, et al. Her2 amplification status in gastric and gastroesophageal junctioncancer in routine clinical practice: which sample should be used? Histopathology 2012;61:1345 